\title{
Drug of Action Cassia Alata Leaves Extract as Antiviral to Dengue Virus Serotype-2 In vitro
}

\author{
Marissa Angelina ${ }^{1,2}$, Muhammad Hanafi ${ }^{2}$, Franciscus D. Suyatna ${ }^{3}$, Beti Ernawati Dewi ${ }^{4, *}$
}

\section{Marissa Angelina ${ }^{1,2}$, Muhammad Hanafi ${ }^{2}$, Franciscus D. Suyatna ${ }^{3}$, Beti Ernawati Dewi ${ }^{4, *}$ \\ ${ }^{1}$ Doctoral Programme in Biomedical Science Faculty of Medicine, University of Indonesia, Jl. Salemba Raya 6, Jakarta 10430, INDONESIA \\ ${ }^{2}$ Research Centre for Chemistry LIPI, Kompleks Puspiptek Serpong 15416, INDONESIA. \\ ${ }^{3}$ Department of Pharmacology and Therapeutics Faculty of Medicine- RSCM Universitas Indonesia, Jl. Salemba Raya 6, Jakarta 10430, INDONESIA. \\ ${ }^{4}$ Departement of Microbiology Faculty of Medicine, Universitas Indonesia- Cipto Mangukusumo Hospital, Jalan Pengangsaan Timur No. 16 Jakarta 10320, INDONESIA.}

\section{Correspondence}

\section{Beti Ernawati Dewi}

Departement of Microbiology Faculty of Medicine, Universitas IndonesiaCipto Mangukusumo Hospital, Jalan

Pengangsaan Timur No. 16 Jakarta 10320 INDONESIA

Phone no: (021) 3160491;

E-mail: betied@yahoo.com

History

- Submission Date: 01-04-2020;

- Review completed: 13-04-2020;

- Accepted Date: 04-05-2020

DOI : 10.5530/pj.2020.12.124

Article Available online

http://www.phcogj.com/v12/i4

\section{Copyright}

(C) 2020 Phcogi.Com. This is an openaccess article distributed under the terms of the Creative Commons Attribution 4.0 International license.

\section{ABSTRACT}

Background and Objectives: Dengue viruses (DENV) is a mosquito-borne members of the Flaviridae family.To date, more than 2.5 billion people in over 100 countries are at risk of infection, and approximately 20 million infections were reported annually. Currently, There is no specific antiviral treatment available for DENV infection. Natural products possess a wide range of biological and biochemical potential. Among them, plants are one of the most important sources for discovering new drugs for therapy. Our previous study, showed that Cassia alata has potency as antiviral to DENV, however drug of action still unclear. Material and Methods: We explore the drug of action of $C$. alata leaves exract and its fraction through time of addition studies and effect of solvents wtih the dose based on the previous study. Result: The most effective inhibition druf of action was determined by focus assay. Meanwhile the toxicity was measured by MTT assay. These studies demosntrated that ethanol extract of Cassia alata $1 \mathrm{mg} / \mathrm{ml}$ showed strong inhibition in both early step (receptor and attachment to host cells) and post infection with inhibition $96.04 \%$ and $99.16 \%$.Compared with those fractions, Cassia alata ethanol extract has strongest inhibition DENV in every step of virus replication. Conclussion: Cassia alata ethanol extract has strongest inhibition DENV in every step of virus replication with the average of inhibition more than $95 \%$. Ethyl acetate and hexane has strongest inihibition with the average of inhibition $100 \%$.

Key words : Dengue virus, Antiviral, Cassia alata, Early step, Post infection.

\section{INTRODUCTION}

Dengue is recently reported to be the most rapidly spreading mosquito-borne viral disease and is endemic in more than 110 countries including Indonesia with two-fifths of the world population at risk. According to the data from Ministry of Health Republic Indonesia, more than 100000 people were diagnosed with dengue fever in the 2014 and were found to be fatal in almost 1000 cases. ${ }^{1}$ An estimated 100 million cases of dengue fever and half a million cases of dengue haemorrhagic fever (DHF) occurred annually. ${ }^{2}$ The clinical presentations of DENV infections range from asymptomatic to severe illness that may lead to death if improperly managed. The symptomatic cases are categorized as undifferentiated febrile illness (UF), dengue fever (DF), dengue hemorrhagic fever (DHF), dengue shock syndrome (DSS) and unusual dengue (UD) or expanded dengue syndrome (EDS). ${ }^{3}$

The disease is caused by dengue virus (DENV) which exists as four closely related, but antigenically distinct virus serotypes of DENV-1 to DENV-2. ${ }^{2}$ This leads to many challenges in the development of a vaccine that would provide solid immunity equally to all serotypes. ${ }^{3}$ Another approach of viral diseases control is directed toward antiviral against DENV. During several decades a research has been explored natural products from medicinal plants due to the advantages of high chemical diversity of these biologically active molecules and lower cost. Many plant composition such as flavonoids, terpenoids, lignin, alkaloids, tannins, polyphenolics, coumarins, saponins, and chlorophyllins, are reported have anitival activity to DENV. ${ }^{4-6}$ Therefore, natural products from herbal medicine represent an alternative approach for treatment of DENV infections. Research for dengue antiviral has focused on the different phases of the viral lifecycle (virus attachment, viral entry, trafficking, translation or replication).

Nevertheless, only few antiviral therapies have been tested and little is known about the effects and mechanisms of the antiviral agents. ${ }^{4}$ Our study previously reported inhibitory activity of $C$. alata extract against DENV-2 and its toxicity to Huh-7 it-1 cells, but the inhibitory mechanism and chemical content of C. alata is already unknown.

This study aims to evaluate drug of action Cassia alata leaves extract and its fraction as antiviral DENV-2 using cell culture model and knowing the compounds contained in Cassia alata.

\section{MATERIAL AND METHODS}

\section{Study design}

This study was an experimental study using Huh7 it-1 cell line for pursuing the DENV antiviral mechanism. Compounds identification of C. alata was performed using LC-MS / MS.

\section{Preparation of extrac}

The boanical identities of Cassia alata leaves extract was determined and authenticated by the Botanical

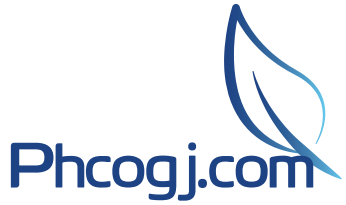

Cite this article: Angelina M, Hanafi M, Suyatna FD, Dewi BE. Drug of Action Cassia Alata Leaves Extract as Antiviral to Dengue Virus Serotype-2 In vitro. Pharmacogn J. 2020;12(4):86471. 
in Research Center for Biology LIPI. After the taxonomy identification, the Cassia alata leaves were washed and cleaned prior to air drying at room temperature. Dried and ground leaves $(1000 \mathrm{~g})$ were submitted to extraction at room temperature with ethanol $70 \%$. The solvent was removed used vaccum evaporator yielding $225.7 \mathrm{~g}$ of the thick extract. The extract $(60 \mathrm{~g})$ was initially partitioned with $\mathrm{n}$-hexane, ethyl acetate, butanol and water. The solvent was removed used vacuum evaporator yielding $4.2 ; 7.7 ; 7.1$ and $31.5 \mathrm{~g}$ respectivelyExtracts and fractions were diluted at concentration of $100 \mathrm{mg} / \mathrm{ml}$ in dimethyl sulfoxide (DMSO) (Sigma Aldrich, USA) as a stock solution. ${ }^{7}$

\section{Identification compound of C. alata extract using LC/ MS-MS}

Mass spectrometry was performed on a Xevo, G2-XS QTof (Waters MS Technologies). Ionisation type is ESI. The scan range was from 100 to $1200 \mathrm{~m} / \mathrm{z}$. The capillary and cone voltage was set at $0.8 \mathrm{kV}$ and $30 \mathrm{kV}$, respectively and was used positive electro spray mode. The desolvation gas was set to $1000 \mathrm{~L} / \mathrm{h}$ at a temperature of $500^{\circ} \mathrm{C}$ and the cone gas was set to $50 \mathrm{~L} / \mathrm{h}$ and the source temperature was set to $120^{\circ} \mathrm{C}$. The UPLC analysis was performed using a Waters Acquity Ultra Performance LC system. Chromatographic separation was carried out on an ACQUITY UPLC HSS T3 C18 column $(100 \mathrm{~mm} \times 2.1 \mathrm{~mm}, 1.7 \mu \mathrm{m})$ at a column temperature of $40{ }^{\circ} \mathrm{C}$. The mobile phase consisted of solvent A $(0.1 \%$ formic acid in water, v/v) and solvent B $(0,1 \%$ formic acid in acetonitrile), with gradient polarity from 95:0.5 (A: B) to 0.5:95 (A: B). The flow rate was set at $0.3 \mathrm{~mL} / \mathrm{min}$. The column and auto sampler were maintained at $40^{\circ} \mathrm{C}$ and $20^{\circ} \mathrm{C}$, respectively. The injection volume was $1 \mu \mathrm{L}$.The data acquisition and processing were performed using UNIFI. The parameter used was retention time (RT) in the range of 1- 15 min. Determination of the dominant compound was carried out with semi quantitative determination based on the high intensity of the compound on the LC-MS/MS graph.

\section{Preparation of DENV-2 and Huh-7-it-1}

We used DENV serotype 2 strain New Guinea C (DENV-2 NGC) adapted in Huh-7-it-1 cell line. A monolayer of Huh-7-it-1 cell in T-75 flasks were infected with DENV-2 NGC with moi of $0.5 \mathrm{PFU} /$ cell and incubate at $37^{\circ} \mathrm{C}$ with $5 \% \mathrm{CO}_{2}$ for 7 days. During the time of virus propagation, the FBS concentration of the cell culture medium was reduced to $2 \%$. Supernatant was harvested and centrifuged at $1000 \mathrm{~g}$ for 5 minutes. Culture supernatant was stored at $-80^{\circ} \mathrm{C}$ and checked for the titer of dengue virus by Focus assay. ${ }^{8,9}$

\section{Determination of cytotoxicity}

In vitro cytotoxicity was determined by MTT assay based on viability of Huh-7-it-1 after treated with extract. In 48 well flat-bottom plates (Corning, USA), we added $5 \times 10^{4}$ cells/well and incubated at $37^{\circ} \mathrm{C}$, $5 \% \mathrm{CO}_{2}$ for 24 hours. After 24 hours, the cells were treated with various concentration of extract from 0.1 to $80 \square \mathrm{g} / \mathrm{mL}$ and incubated at $37^{\circ} \mathrm{C}, 5 \% \mathrm{CO}_{2}$. After 48 hours, $20 \mu \mathrm{L}$ of 3-(4,5-Dimethylthiazol-2yl)- 2,5-diphenyltetrazolium bromide (MTT) (Promega) salt solution was added into each well and incubated for 4 hours according to the manufacturer's instruction. The absorbance reading of each well was measured using micro plate reader at $490 \mathrm{~nm} .{ }^{7}$ The percentage of cell viability and toxicity was further determined based on the absorbance readings. First, we calculate the theoretical percentage toxicity of the samples by dividing the mean blanked sample ODs by the mean blanked control ODs for each sample. We used the viability data correspond to the cytotoxic effect. ${ }^{8,10}$

\section{Determination mechanism of antiviral action of CA and} its fractions

To determine mechanism of antiviral action that would explain the possible inhibitory step(s) in the viral life cycle, we used published method with slight modification. ${ }^{11,12}$ We carried out a time-of-addition study with the concentration of CA and it's fractions of $10 \mathrm{mg} / \mathrm{mL}$ and monolayer $\left(5 \times 10^{4}\right.$ cells/well) Huh-7-it- 1 at 48 well plate.

For inhibition of DENV receptor (i), we added extract or fractions into cell for 2 hours before DENV infection at $37^{\circ} \mathrm{C}$ with $5 \% \mathrm{CO}_{2}$, The residual extract or fraction were removed and washed. Then DENV-2 was infected into cells for for 2 hours at $37^{\circ} \mathrm{C}$ with $5 \% \mathrm{CO}_{2}$. After virus adsorption, the remain virus was removed and the medium without extract was added and incubated for 48 hours. For entry step experiment (ii), DENV-2 was mixed with extract or fractions at concentration of $10 \mathrm{ug} / \mathrm{mL}$, then infected to the cell for 2 hours at $37^{\circ} \mathrm{C}$ with $5 \% \mathrm{CO}_{2}$. After virus adsorption, the residual virus and test sample were removed and washed. Then the cells were added with medium and incubated at $37^{\circ} \mathrm{C}$ with $5 \% \mathrm{CO}_{2}$ for 48 hours. Post entry step experiment (iii), DENV-2 was infected to the cells for 2 hours, and removed the residual virus. The cells were added with medium containing of Extract and its's fraction and incubated for 48 hours. The whole step experiment or prepost experiment (iv) was combaining of pre and post experiment. The DENV-2 were treated with exctrat or it's fraction prior infection and followed by addition of medium with medium containing of extract and its's fraction As a positive control: we infected cells with DENV-2 and the cells were added with medium without extract of it's fraction for $48 \mathrm{hr}$.

After 48 hours, then we harvest and determine virus titer by focus assay with the same method above. ${ }^{8,11}$. The result from focus assay was used to determine percentage of virus inhibition..$^{8,13}$

\section{RESULTS AND DISCUSSIONS}

\section{Profile of LC-MS/MS of Cassia alata leaf extract and fractions}

Chemical constituents of Cassia alata leaves were reported: aloe emodin, emodin, $\omega$-hydroxyemodin, lunatin, physcion, ziganein, apigenin, 7,4'-dihydroxy-5- methoxyflavone, diosmetin, kaempferol, luteolin, trans-dihydrokaempferol, trans-resveratrol. ${ }^{14,15} \mathrm{C}$. alata leaf extract has been reported to have various pharmacological activities including antibacterial , cytotoxicity, anti-inflammatory, antidiabetic, antihepatotoxic and hepatoprotective effects, antiseptic, antiviral and exhibited strong DPPH radical scavenging activities. ${ }^{16-19}$

Whereas from the measurement data using LC-MS / MS (Figures 1-5), it is known that Cassia alata leaves contain 5,7,2', 5'- Tetrahydroxyflavone, Daturametelin H, Kaempferol-3,7- diglucoside, $\beta$-sitosterol-3-0- $\beta$ -D-glucopiranoside, Digitopurpon, 25-Dehydroxy-24-acetate alisol, 3,3 ', 5,5-Tetramethoxy-trans-stilbene, Deoxycholic acid. It can be seen that several differences compounds measured by LC-MS/MS with previous research reports suggest that a number of things that affect the difference in compound content are the location where the plants grow, the time of harvesting leaves and solvents and the extraction process. ${ }^{20}$ There are differences in the dominant compounds in each fraction due to differences in the polarity of each fraction. Polar compounds will be dominant in the more polar fraction and conversely the non-polar compound will be dominant in the more non-polar fraction (Table 1, Figures 1-5).

\section{Cytotoxicity of C. alata extract and fractions on the Huh7 it-1 cell line}

Based on previous tests it was known that CA, CA1, CA2, CA3, CA4 had DENV antiviral activity on Huh 7-it-1 cell with the focus assay method, where there was a decrease in the focus on dengue-infected Huh 7-it-1 cells. ${ }^{7}$ Moreover, we want to investigate antiviral DENV mechanisms from extracts of CA, CA1, CA2, CA3, and CA4 through time addition 


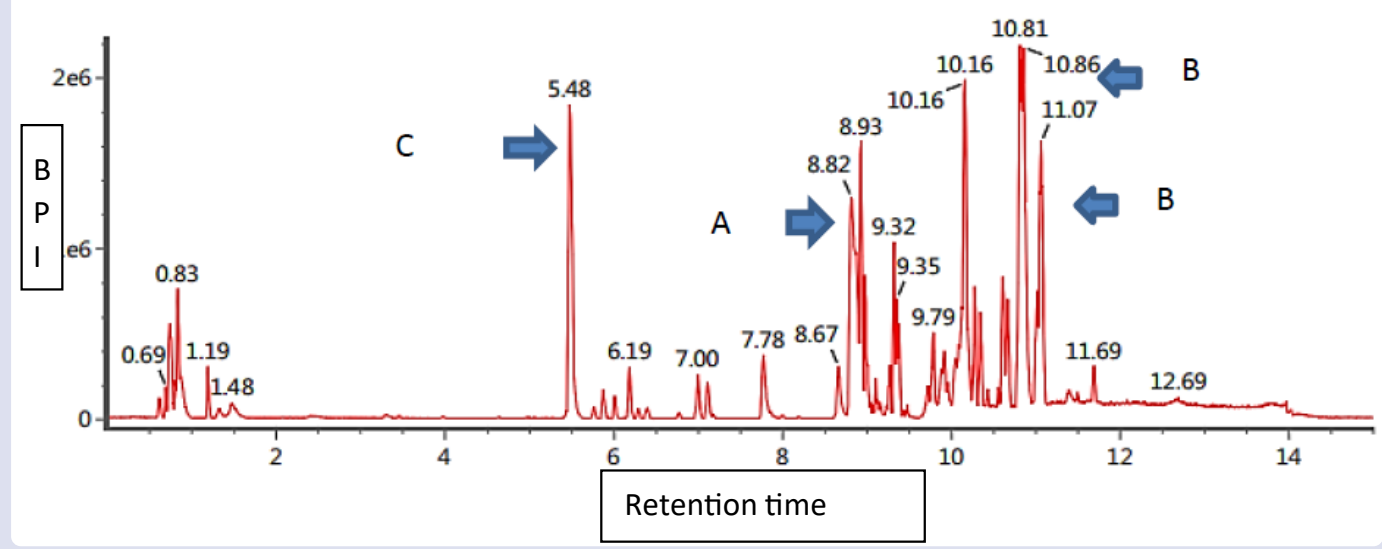

Figure 1: LC-MS of C. alata ethanol extract A. 5,7,2','- Tetrahidrox-flavone, B. Daturametelin H, C. Kaempferol- 3,7diglukoside.

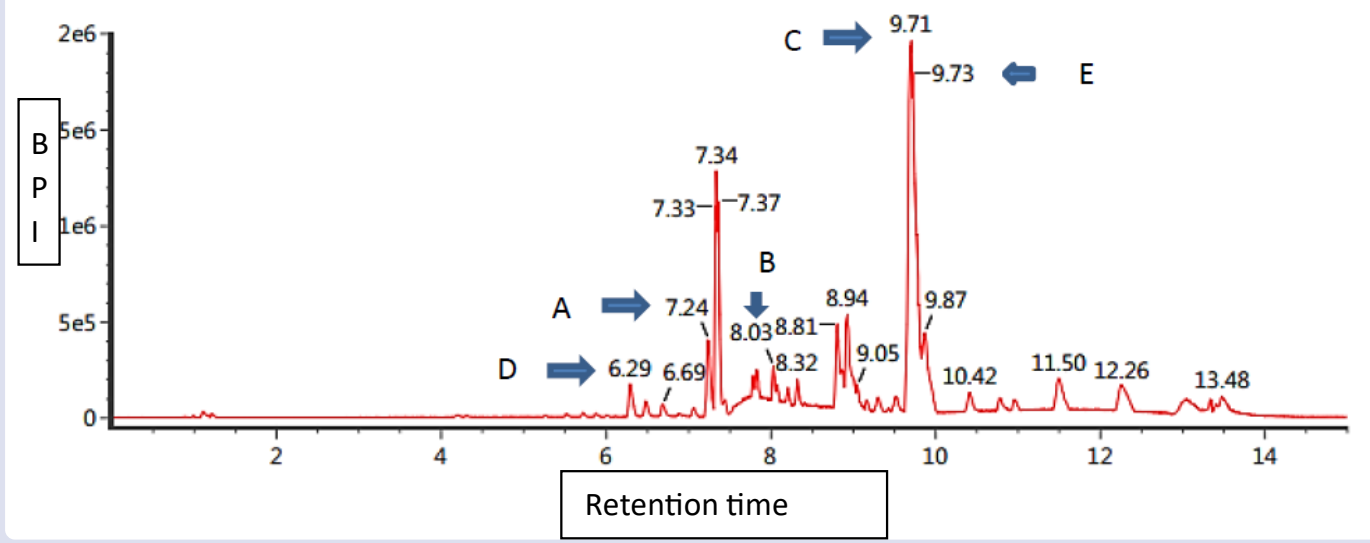

Figure 2: LC-MS C. alata n-heksane extract A. 5,7,2',5'- Tetrahidrox-flavone, B. Clinopodiside F C. Daturametelin H, D. Kaempferol- 3,7- diglukoside, E. a-sitosterol-3-0-8-D-glukopiranoside.

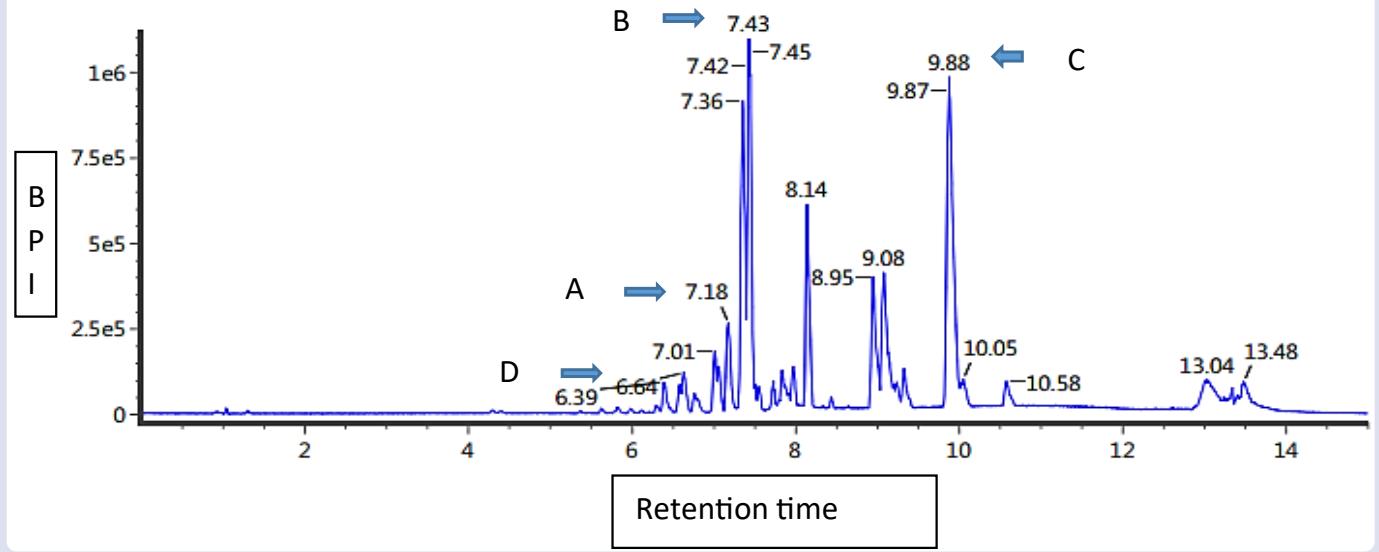

Figure 3: LC-MS C. alata etil asetat fraction A. 5,7,2', $5^{\prime}-$ Tetrahidrox-flavone, B. Digitopurpon, C. Daturametelin H, D. Kaempferol- 3,7- diglukoside. 


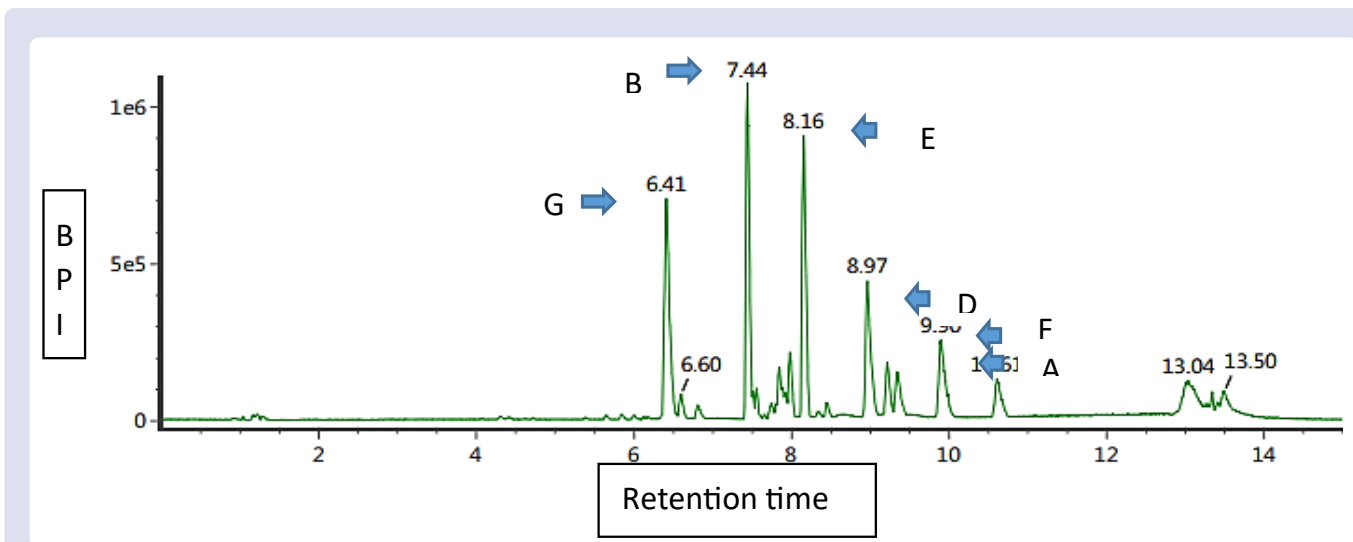

Figure 4: LC-MS C. alata butanol fraction A. 25-Dehydroxy-24-acetate alisol B. 3,3'5,5'-Tetramethoxy-trans-stilbene, C. 5,7,2',5'- Tetrahidrox-flavone, D. Bis(2-ethylhexyl)phthalate, E. Deoxycholic acid, F. Epianhydrobelachinal, G. Kaempferol-3,7- diglukosida.

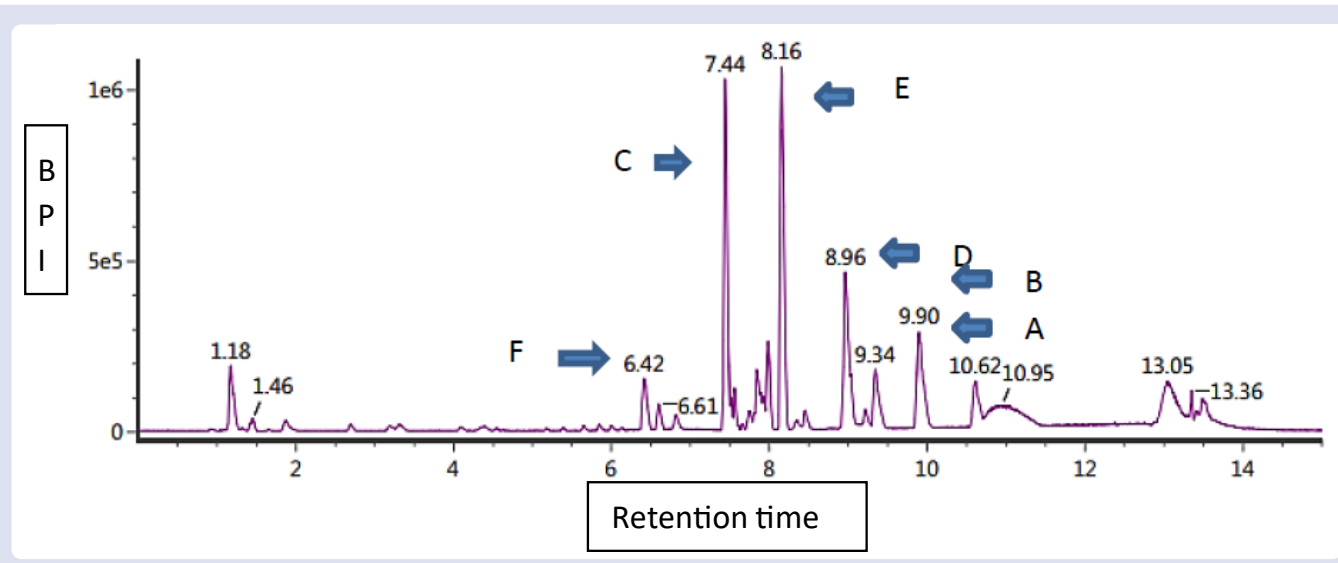

Figure 5: LC-MS C. alata water fraction A. 21-O-Methyltoosenddanopentanol, B. 25-Dehydroxy-24-acetate alisol, C. 3,3'5,5'-Tetramethoxy-trans-stilbene, D. Bis(2-ethylhexyl)phthalate, E. Deoxycholic acid, F. Kaempferol- 3,7diglukosida.

studies. To be a potential antiviral drug the extract not only has to be able to inhibit growth of the virus, but also remain harmless to the cells. Therefore, we determine the toxicity after the cells were treated with extact and it's fraction at concentration of $10 \mu \mathrm{g} / \mathrm{mL}$ using MTT assay. CA, CA1, CA2, CA3 and CA4 showed no toxic effect to the cell based on the percentage of viability cell of Huh7 it-1 (Table 2).

\section{Time of addition studies cassia alata leaves extract and fractions}

Dengue virus (DENV) infection begins with the attachment of a viral capsid protein to the receptor (attachment) which in turn mediates endocytosis through the formation of endosomes with low $\mathrm{pH}$ and induces fusion of DENV. ${ }^{21,22}$ This stage can be a target of antivirals where obstacles to the viral envelope or parts of cell receptors will prevent infection. In this study the resistance to virus particles was directly tested by exposing CA, CA1, CA2, CA3, CA4 to DENV-2 isolates, then inoculating the cells. The result of viral titers at the addition of CA at a dose of $10 \mu \mathrm{g} / \mathrm{ml}$, inhibition reached $99.28 \%$. While the virus inhibition after the addition of CA1, CA2, CA3, CA4 were 92, 63, 85 and $89 \%$, respectively. CA has the most potent activity in damaging the integrity of membranes on the surface of virus particles.
The next test is the addition of CA, CA1, CA2, CA3, CA4 extract to the medium after the cell is infected. The test results provide inhibition of $99.06 \%$ at the concentration of CA $10 \mu \mathrm{g} / \mathrm{ml}$. Whereas for fractions of CA1, CA2, CA3 and CA4 fractions give inhibitions of 100, 100, 88, 87\% respectively (Figure 6).

The non-polar fraction of hexane (CA3) and ethyl acetate (CA2) gave better results in the post-infection mechanism. It was estimated that the content of non-polar compounds found in the fraction of CA2 were an active compouds to inhibit DENV. Analysis with LC-MS / MS, known that the CA2 and CA3 contain several same compounds i.e. ,7,2 ', 5'- Tetrahidrox-flavone, Daturametelin H and Kaempferol-3,7diglukoside. In this mechanism, after infection, antiviral is continuously present in the culture medium. In a previous study reported tests on vero cells added with medium and curcumin and incubated for one day showed that curcumin can accumulate in cells when detected using a confocal microscope. ${ }^{23}$

This result indicates CA, CA1, CA2, CA3, CA4 can inhibit DENV replication in cells. CA is an ethanol extract that is semipolar in nature, presumably the nonpolar part of CA which is lipophilic can penetrate the cell membrane. ${ }^{22}$ Replication of the viral genome occurs 
Table 1: Identification compound of ethanol extract of C. alata, $\mathbf{n}$-hexane fraction, ethyl acetate fraction, butanol fraction and water fraction.

\begin{tabular}{|c|c|c|c|c|}
\hline Extract/Fraction & Compounds & Retention time (Rt) & $\begin{array}{c}\text { Molecule } \\
\text { weight }\end{array}$ & Intensity \\
\hline \multirow{4}{*}{ Ethanol Extract } & $5,7,2^{\prime}, 5^{\prime}$ - Tetrahidrox-flavone & 8,82 & 287,05 & ++ \\
\hline & Daturametelin $\mathrm{H}$ & 10,86 & 621,31 & +++ \\
\hline & Kaempferol-3,7- diglukosida & 5,48 & 611,16 & ++++ \\
\hline & $5,7,2,5$ '- Tetrahidrox-flavone & 7,24 & 287,06 & +++ \\
\hline \multirow{3}{*}{$\begin{array}{l}n \text {-Heksana } \\
\text { Fraction }\end{array}$} & Klinopodisida F & 8,03 & 991,55 & + \\
\hline & Daturametelin $\mathrm{H}$ & 8,94 & 621,3 & + \\
\hline & Kaempferol-3,7-diglukosida & 6,29 & 633,14 & + \\
\hline \multirow{6}{*}{$\begin{array}{l}\text { Ethyl acetate } \\
\text { fraction }\end{array}$} & $\square$-sitosterol-3-0-凹-D-glukopiranosida & 9,73 & 559,43 & ++++ \\
\hline & $5,7,2,5$ '- Tetrahidrox-flavone & 7,36 & 287,06 & ++++ \\
\hline & Digitopurpon & 7,43 & 271,06 & +++ \\
\hline & Daturametelin $\mathrm{H}$ & 9,88 & 621,3 & ++++ \\
\hline & Kaempferol-3,7-diglukosida & 6,64 & 633,14 & + \\
\hline & 25-Dehydroxy-24-acetate alisol A & 10,61 & 537,36 & \\
\hline \multirow{5}{*}{$\begin{array}{l}\text { Butanol } \\
\text { fraction }\end{array}$} & 3,3'5,5'-Tetramethoxy-trans-stilbene & 7,44 & 301,14 & + \\
\hline & 5,7,2',5'-Tetrahydroxy-flavone & & 287,06 & ++++ \\
\hline & Bis(2-ethylhexyl)phthalate & & 413,27 & ++ \\
\hline & Deoxycholic acid & 8,16 & 393,3 & ++++ \\
\hline & Epianhydrobelachinal & 9,9 & 469,33 & + \\
\hline \multirow{7}{*}{$\begin{array}{l}\text { Water } \\
\text { fraction }\end{array}$} & Kaempferol-3,7-diglucoside & 6,41 & 611,16 & +++ \\
\hline & 21-O-Methyltoosenddanopentanol & 10,62 & 521,38 & + \\
\hline & 25-Dehydroxy-24-acetate alisol A & 9,9 & 637,36 & + \\
\hline & 3,3,5,5'-Tetramethoxy-trans-stilbene & 7,44 & 301,14 & ++++ \\
\hline & Bis(2-ethylhexyl)phthalate & 8,96 & 413,27 & ++ \\
\hline & Deoxycholic acid & 8,16 & 393,3 & ++++ \\
\hline & Kaempferol-3,7-diglucoside & 6,42 & 633,14 & + \\
\hline
\end{tabular}

Table 2: Viability cells after treatment with C. alata leaves extract and its sub fractions.

\begin{tabular}{|c|c|c|c|c|c|}
\hline \multirow[t]{2}{*}{ Treatments } & \multicolumn{5}{|c|}{ Viability Cells (\%) } \\
\hline & CA & CA1 & CA2 & CA3 & CA4 \\
\hline Reseptor & $68,91 \pm 15,23$ & $75,37 \pm 6,49$ & $109,64 \pm 12,12$ & $110,32 \pm 4,59$ & $143,79 \pm 4,64$ \\
\hline Whole & $75,54 \pm 11,76$ & $97,21 \pm 0,77$ & $113,39 \pm 7,6$ & $171,35 \pm 6,07$ & $98,34 \pm 18,87$ \\
\hline Post & $121,27 \pm 45,07$ & $100,58 \pm 00,4$ & $144,19 \pm 22,13$ & $262,28 \pm 4,56$ & $139,67 \pm 22,13$ \\
\hline Pre & $118,08 \pm 10,93$ & $95,33 \pm 5,17$ & $126,71 \pm 12,72$ & $149,59 \pm 25,03$ & $131,08 \pm 0,37$ \\
\hline
\end{tabular}

CA- Crude ethanol extract • CA1 - Hexane fraction • CA2 - Ethyl acetate fraction • CA3 - Buthanol fraction • CA4 - Water fraction.

in the cytoplasm, then towards the endoplasmic reticulum where viral particles are assembled, antiviral accumulation in the cell cytoplasm is thought to interfere with the DENV replication process. ${ }^{24}$

In the treatment where exposure of CA, CA1, CA2, CA3, CA4 before infection to DENV-2 and the addition of CA to the medium after the infected cell gave a maximum barrier of $99.06 \%$, whereas when compared to the results of inhibition at the attachment and postinfection stages CA was concluded to be better inhibited at the postinfection stage (Figure 6).

While in the treatment of CA exposure to cells or receptor blocks, the inhibition percentage was $96.04 \%$ (Figure 6). The possible inhibition mechanism of CA in this way is on the cell membrane by the accumulation of CA, as well as things related to replication in the cell. These results indicate that to be able to inhibit DENV replication in cells exposed to CA for 2 hours, CA requires a concentration of $10 \mu \mathrm{g} /$ $\mathrm{ml}$.

These studies demosntrated that ethanol extract of Cassia alata showed strong inhibition in both early step (receptor and attachment to host cells) and post infection with inhibition $96.04 \%$ and $99.16 \%$ (Figure 6).Compared with those fractions, Cassia alata ethanol extract has strongest inhibition DENV in every step of virus replication. We supposed the antiviral activity of CA extract is influenced by the 


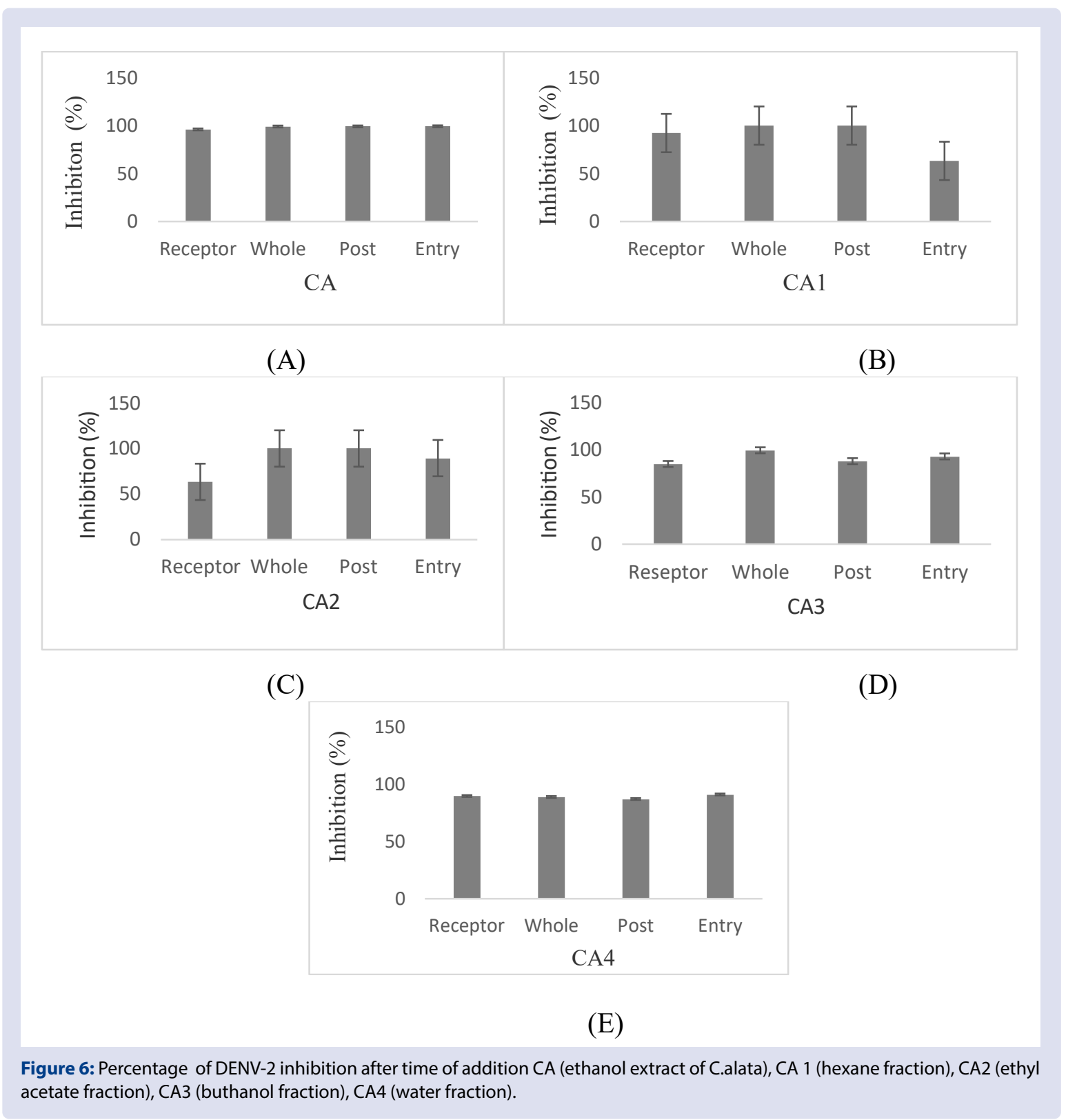

compounds contained in the extract. Kaempferol -3,7-diglukoside is the highest intensity compound contained in CA extracts compared to fractions. From the previous research, it was reported that kaempferol glycosides are good candidates as antiviral for 3a channel proteins of coronaviruses. ${ }^{25}$ To know the mechanism more deepply especially which protein of DENV was inhibit by CA and fraction could be investigate through bioinformatic and enzymatic testing of each protein DENV.

\section{CONCLUSSION}

Cassia alata ethanol extract has strongest inhibition DENV in every step of virus replication with the average of inhibition more than $95 \%$. Ethyl acetate and hexane has strongest inihibition with the average of inhibition $100 \%$

\section{ACKNOWLEDGEMENTS}

The authors would like to extend special appreciation to Saintek Kemenristek-BRIN Scholarship, research funding by PDUPT RISTEKDIKTI 2019 and Lia Meilawati for special assintance in extraction process.

\section{CONFLICTS OF INTEREST}

The authors declare no conflicts of interest.

\section{REFERENCES}

1. Kemenkes RI. Profil Kesehatan Indonesia Tahun 2014 Kementerian Kesehatan $\mathrm{RI}, 2015$.

2. Halstead SB Handbook for clinical management of dengue. World Health Organization , 2012.

3. WHO. Comprehensive guidelines for prevention and control of dengue and dengue haemorrhagic fever, revised and expanded. World Health Organization Regional Office for South-East Asia, 2011.

4. Panichayupakaranant $P$, Sakunpak A, Sakunphueak A. Quantitative HPLC determination and extraction of anthraquinones in Senna alata leaves J Chromatogr Sci. 2009;47(3):197-200.

5. Zige D V., Ohimain El, Nengimonyo B. Antimicrobial activity of ethanol extract of Senna alata Leaves against some selected microorganism in Bayelsa State, Nigeria. Greener J Microbiol Antimicrob. 2014;2(2):26-31.

6. Wikaningtyas $P$, Elin $Y$. Sukandar. The antibacterial activity study of senna alata leaf extract and fraction toward MRSA (methicilin-resistant staphylococcus aureus) and its mode of action. W. Journ.of pharm sci. 2015;4(4):126-33. 
7. Angelina M, Hanafi M, Suyatna F.D, T. Mirawati, Ratnasari S ,Dewi B.E. Antiviral Effect of Sub Fraction Cassia alata Leaves Extract to Dengue Virus Serotype-2 strain New Guinea C in Human Cell Line Huh-7 it-1. IOP Conf Ser Earth \& Envi Science. 2017;101(1):120-4

8. Zandi K, Teoh BT, Sam SS, Wong PF, Mustafa MR, Abubakar S. Antiviral activity of four types of bioflavonoid against dengue virus type-2. J virol. 2011;28(8):560.

9. Dewi BE, Fithriyah, Andriansjah R, Paisal, Deka L, Tjahjani M S. Cloning and Expression of Nonstructural Protein NS1 of Dengue Virus Serotype 2. Ind.Soc for Microbiol. , 2020 Vol 6 no 1.

10. M Ichsyani, A Ridhanya, M Risanti, H Desti, R Ceria, DH Putri, et al. Antiviral Effects of Curcuma longa L. Againts dengue virus in vitro dan in vivo. IOP Conference Series Earth and Enviromental Science 2005

11. Kamboj A. Ajay K Saluja, Munish Kumar, Pooja Atri. Antiviral activity of plant polyphenols. J of Pham Res. 2012:5(5):2402-241.

12. Apriyanto DR, Aoki C, Hartati S, Hanafi M, Kardono LB, Arsianti A, et al. AntiHepatitis $C$ virus activity of a crude extract from Longan (Dimocarpus longan Lour.) leaves. Jpn J Infect Dis. 2016; 69(3):213-20.

13. Payne AF, Binduga G., Kauftman E G, Kramer E D. Quantification of flavivirus by flouresecent focus assay. J Virol Meth. 2006;134:11-21.

14. Promgool T, Pancharoen $O$, Deachathai $S$. Antibacterial and antioxidative compounds from Cassia alata Linn. Songklanakarin J Sci Technol. 2014;36(4):459-63

15. Kumar P.M. Isolation and characterization of a compound from the leaves of Cassia alata Linn... EC Chemistry. 2016:138-44.

16. Chang SJ, Huang SH, Lin YJ, Tsou YY, Lin CW. Antiviral activity of Rheum palmatum methanol extract and chrysophanol against Japanese encephalitis virus. Arch Pharm Res. 2014;37(9):1117-25.
17. Zige D V, Ohimain El, Nengimonyo B. Antimicrobial activity of ethanol extract of Senna alata Leaves against some selected microorganism in Bayelsa State, Nigeria. Greener J Microbiol Antimicrob. 2014; 2(2):26-31.

18. Igwe OU, Onwu FK. Leaf essential oil of Senna alata Linn from South East Nigeria and its antimicrobial activity. Int J of res in pharm \& Chem. 2015;5(1):27 33.

19. Kazeem MI, Azeez GA, Ashafa AOT. Effect of senna alata (L) roxb (fabaceae) lea extracts on alpha-amylase, alpha-glucosidase and postprandial hyperglycemia in rats. Trop J Pharm Res. 2015;14(10):1843-8.

20. Artanti N, Triana Dewi R, Maryani F. The effect of location and extraction solvent on phytochemical content and antioxidant activity of Pegagan extract (Centela asiatica L. Urb). JKTI. 2014;16(2 ):13-9.

21. Igarashi A. Impact of dengue virus infection and its control. J Path \& dis. 1997:18(42):87-93.

22. Jaruga E, Salvioli S, Dobrucki J, Chrul S, Bandorowicz Pikula J, Sikora E Apoptosis like, reversible changes in plasma membrane asymmetry and permeability, and transient modification in mitochondrial membrane potential induced by curcumin in rat thymocyes. FEBS Lett. 1998;433(3);234-41.

23. Herman Reni. Efek antivirus dan antiinflamasi senyawa kurkumin terhadap infeksi virus dengue, In vitro. Disertation report of Doctoral of Biomedic program Medical Faculty University of Indonesia, 2016.

24. Perera R, Kuhn RJ. Structural proteomics of dengue virus. Curr opin Microbiol. 2008;11(4):369-77

25. Schwarz S, Daniel Sauter, Kai wang. Evaluation of antiviral activity of kaempfero and its glycosides againts human cytomegalovirus. Plan Med. 2000;66(4):377-

\section{GRAPHICAL ABSTRACT}

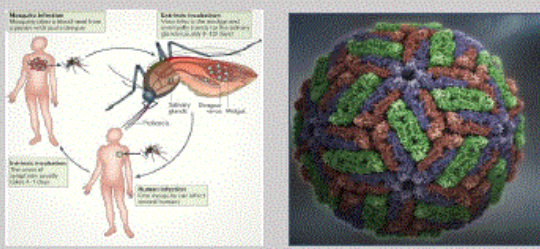

Antivirus

Cassia alata Linn

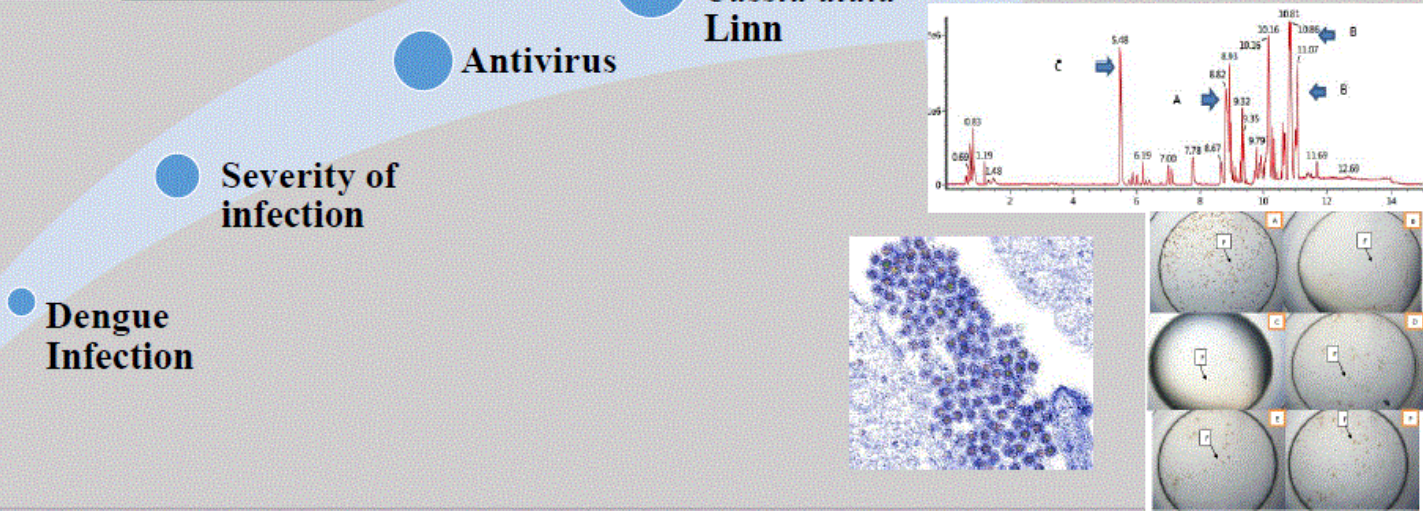

\section{ABOUT AUTHORS}

Marissa Angelina: Researcher at Research Centre for Chemistry, Indonesian Institutes of Sciences (LIPI), Serpong , Indonesia.

Muhammad Hanafi: Researcher at Research Center for Chemistry, Indonesian Institute of Science, Serpong, (LIPI) Indonseia. 
Franciscus D. Suyatna: Department of Pharmacology and Therapeutics Faculty of Medicine Universitas Indonesia, Cipto Mangukusumo Hospital JI. Salemba Raya 6, Jakarta 10430, Indonesia.

Beti Ernawati Dewi: Departement of Microbiology Faculty of Medicine, Universitas Indonesia-, Jalan Pengangsaan Timur No. 16 Jakarta Indonesia 10320.

Cite this article: Angelina M, Hanafi M, Suyatna FD, Dewi BE. Drug of Action Cassia Alata Leaves Extract as Antiviral to Dengue Virus Serotype-2 In vitro. Pharmacogn J. 2020;12(4):864-71. 